\title{
Russian Experience of Patriotic Education: Generalization Tendencies of the Consensus around Militarism
}

\author{
Andrey Koshkin ${ }^{1},{ }^{*}$ Egor Moroz ${ }^{1}$, Aleksandr Yankilevich ${ }^{1}$, Daria Andreeva ${ }^{1}$ \\ ${ }^{1}$ St. Petersburg State University, Russia \\ *Email: koshkin99300@mail.ru
}

\begin{abstract}
In this article, the authors attempt to analyze the facts that indicate a tendency to militarize the patriotic education of Russian young people. Luhmann's institutionalization concept was chosen as a theoretical model and methodological basis for the study. Based on empirical data collected at the XIV-th City Interdepartmental Competition of the Patriotic Song "I Love You, Russia!" concerns were expressed that along with the relative ease of generalizing consensus, military patriotism, especially naturally consolidated around the Great Patriotic War, is a direct threat to the militarization of young people and the reduction of society's need for apperception of non-violent methods of resolving inter-ethnic and interpersonal conflicts. In turn, the meaningful and selective representation of the consolidated "us" / "them" system can lead to the self-reproducing substitution of the concept of "love for the Motherland" for "defense of the Motherland," which despite its relative simplicity in generating a consensus around military patriotism for state bodies and programs cannot be called a positive trend.
\end{abstract}

Keywords: Patriotic education, Militarization, Luhmann, Patriotism.

\section{INTRODUCTION}

The issue of value orientations is one of the most urgent for modern Russian society. Despite the fact that almost 30 years have passed since the collapse of the Soviet Union, the ideological vacuum formed as a result of the dismantling of the Soviet ideological model remains unfilled to this day. The rejection of the Marxism-Leninism postulates, the rapid transition to a market economy and, as a consequence, a complete change in moral and value orientations led to mass frustration throughout the society. This negative effect was further intensified by the many-fold increase in social inequality: the emergence of categories of the super-rich and poor citizens introduced an additional disintegration into the social structure. The search for an ideological and value model, a "national idea" capable of re-uniting the Russian society has been going on for over thirty years, and today this process can hardly be considered complete.
At the same time, it should be noted that among the ideas claiming the "new ideology" status in modern Russia, patriotism is the most popular and influential one. Much attention is paid to patriotism at the state level: references to this concept are regularly heard in representatives' speeches of the ruling elite and the country's leadership, and there has been a "Patriotic education of citizens of the Russian Federation for 20162020 " state program for the last 5 years in Russia. At the same time, it should be noted that the idea of patriotism finds a great response from the population of the country: according to a poll by the Russian Public Opinion Research Center, $92 \%$ of the country's citizens consider themselves patriots. At the same time, the contradictory nature of Russian patriotism is noted: due to the ideological contradictions of modern Russia and the Soviet Union, the 1917 to 1991 events of national history are considered outside the socio-economic, political and ideological context [1]

Since the transfer of socially significant norms and values to the younger generation is one of the highest 
priority tasks for any state, great attention is also paid to the issue of patriotic education of young citizens of Russia. On October 29, 2015, the President of the Russian Federation signed Decree No. 536 On the establishment of the All-Russian public-state children's and youth organization "Russian movement of schoolchildren". Less than a year later, on July 29, 2016, the all-Russian youth military-patriotic public movement known as "Yunarmiya" was registered. Today, these movements unite over 423 thousand schoolchildren aged 8 to 17 years. At the same time, within the framework of "Yunarmiya" [2] and the "Russian Movement of Schoolchildren" [3] much attention is paid to the patriotic education of young citizens of the country.

\section{RESEARCH METHODOLOGY}

The researchers note that the unstable emotional state of a teenager, the development of self-awareness, the choice of priorities and values, inadequate self-esteem, dissatisfaction with oneself and other people - all these phenomena make it possible to attribute him/her to a high-risk group and, at the same time, to consider him/her as an attractive object on the part of various "mind hunters," write Rensch, Ryabina and Biserov. [4]. In connection with the restructuring of the social control mechanisms, "borderline" and the uncertainty of social status are formed. A hierarchical system of motives is created in adolescence. Undoubtedly, adult ways of behavior, which imply self-discipline and self-control, have not yet developed and strengthened, and the demands of obedience from adults and the inherent children's forms of control no longer act on them, which is noted in the study of A. Vilkomirsk [5].

The phenomenon of "military and patriotic education" itself has its roots in the Soviet era because in fact the Yunarmiya and partly the Russian Movement of Schoolchildren are analogs of the Pioneer Organization in the Soviet Union except that not a specific ideology is proclaimed as the ideological basis as it was the case with Marxism-Leninism but a certain abstract "patriotism. This patriotism is in demand and enjoys great popularity both among the population (92\% of people consider themselves patriots [1]) and the leaders [6] due to the need to fill the "ideological vacuum" that was formed with the collapse of the USSR. However, the state of economic crisis and ideological contradictions between modern Russia and Russia until 1991 do not allow directly referring to the past, from which the "military patriotism" is born, that is, reverence for the military exploits of the past as they are, without referring to the context of these events as being socio-economic and ideological and political, which is more important in the context of ideology.

It seems that this kind of "upbringing" focuses on symbolic constructions that are inextricably linked with the military theme, while the cultural and economic achievements of previous generations fade into the background, which makes it possible to militarize public consciousness, that is, building the identity of society around the need for conducting a constant armed struggle for existence. In this case, patriotism is presumably associated not just with "love for the Motherland", but with "defense of the Motherland." Under such conditions, there is a danger of an involuntary substitution of the concepts of "love the Motherland" and "defend the Motherland". The inadmissibility of an equal sign between these intentions can become the material for a separate study, but even simple questions "Does any defender love the Motherland?" or "Is it possible to love the Motherland in times of peace when it does not need protection?" allow you to seriously doubt the chosen patriotic education model.

At the same time, it should be noted that despite the frequent use of the concept of "patriotism", the semantic content of this term today remains insufficiently specified: even within the framework of the "Patriotic education of citizens of the Russian Federation for 20162020" program, the concept of "patriotism" has never been specifically defined. This lack of clear definitions creates ample opportunities for the interpretation of this concept by various actors. Under these conditions, the concrete representation of the concept of "patriotism" is of particular interest for research.

At the same time, the practice of representing patriotism being carried out in the content of the patriotic education of children and adolescents is of particular research interest since the image of the future Russian society in the coming decades directly depends on this.

$\mathrm{N}$. Luhmann's institutionalization concept [7] used in the context of studying the socialization process was chosen as a theoretical research model. According to Luhmann, society is an autopoetic system, the selfreproduction of which occurs through the process of communication. At the same time, Luhmann singles out two problems that arise in the course of the evolution of society - this is one of integrating a meaningfully selective processing of the world complexity and the other one associated with stabilizing consolidated expectations. Due to the polyvariety of the world around them, individuals are in dire need of systematization and generalization of experience and actions in order to select relevant meanings. These problems are solved in the process of the evolution of society - through the institutionalization, which Luhmann defines as the process of integration and stabilization of the social system. The key concept for the institutionalization process, according to Luhmann, is the concept of "generalization of consensus", within the framework of which actual experience is interpreted and compared with "expectation of expected results".

Based on the definition of the socialization concept proposed in 1978 by researchers Berger and Luckmann 
[8], according to which socialization is a process of a consistent conscious introduction of an individual to the objective society world, we can conclude that the consensus generalization in the process of socialization occurs at the moment when the individual in the process of communication with society accepts socially significant experience, values and social rules of behavior, and society, for its part, accepts the individual as a full-fledged member. With regard to the study of the practice of representing the concept of "patriotism", this theoretical model allows us to focus on how exactly this concept is interpreted in the process of its transmission to the younger generation during the socialization process.

\section{EMPIRICAL PART}

Within the framework of this study, the XIV-th City Interdepartmental Competition of Patriotic Songs "I love you, Russia!" held in March 2020 in St. Petersburg was analyzed. The competition was attended by over 6,000 pupils, students and participants of the Russian movement of schoolchildren of state educational organizations of St. Petersburg from 6 to 17 years old. The purpose of the competition was formulated by the organizers as cultivating a sense of patriotism and developing the moral culture of children and youth by means of musical patriotism-oriented songwriting; the formation of the Russian identity of children and adolescents through creative self-realization in the performing arts, the glorification of people who have chosen as their profession to defend the Fatherland and serve the Motherland, keep in mind the most important events in the history of our country and the heroic glory of Russia [9].

In the course of the research, 110 performances of the participants of the competition were analyzed, which were conditionally divided into two large categories: dedicated to military or civilian topics. Also, within the first group, an additional division of performances was carried out by topic: performances dedicated to the Great Patriotic War, and those dedicated to other wars, armed conflicts or service in the RF Armed Forces. The results obtained were distributed as follows: $63.63 \%$ of performances were devoted to military topics while only $36.37 \%$ of performances were associated with civil topics. As performances devoted to military topics, the following were taken into account: singing songs, reading poems, as well as dancing in a form stylized in one way or another as a military one or containing an open mention or reference to military operations or the armed forces in the plot or inventory provision. At the same time, among the performances dedicated to military topics, a clear predominance of performances dedicated to the topic of the Great Patriotic War was revealed as being equal to 45 out of 70 . (40.9\% of the total number of competition performances). It is worth noting that those performances that were not devoted to military topics were focused on emphasizing national identity or cultural characteristics. Almost all performances are characterized by the designation of the "us" / "them" confrontation, or a clear expression of the unique features of "their" group. Our American colleagues came to similar results of a clear correlation between the severity of self-identification and the tendency to local-patriotic tendencies. In particular, William Astor [10].

Thus, we can observe three key trends - the predominance of "military" content in the performances of the participants of the competition, the significant role of the Great Patriotic War in the theme of performances, as well as a clear-cut orientation of the perception of patriotism as a protection or designation of identity. Within the framework of $\mathrm{N}$. Luhmann's institutional model, it is not just the very fact of the existence of institutionalized practices of the consensus generalization around military patriotism (through various groups and military-patriotic clubs) that is important, but also such contests and their content are absolutely critical. Thus, a very clear connection between the perception of patriotism and military patriotism demonstrates to us the results of Russia's state policy in the field of transferring socially significant experience, values and socially acceptable rules of behavior. In turn, $40.9 \%$ of the entries on the theme of the Great Patriotic War show that the Great Patriotic War continues to be the extreme point of this autopoietic straight line. It is important to note that the self-reproduction of such a system of the consensus generalization around the Great Patriotic War occurs precisely within the framework of the military patriotism supported by state programs. This is facilitated by the "Immortal Regiment" tradition "nationalized" by state structures with a pronounced military-patriotic overtones and arranged to coincide with the anniversary of the USSR Victory in the Great Patriotic War, which was originally an action of civil solidarity. However, the fact that such a mass action was born and gained significant popularity outside state structures and programs further confirms our hypothesis about the military-patriotic bias of a meaningfully selective processing of the consolidated expectations of the social system.

\section{CONCLUSION}

It is important to note that along with the relative simplicity in the consensus generalization, military patriotism, especially naturally consolidated around the Great Patriotic War is a direct threat to the militarization of young people and a decrease in society's need for apperception of non-violent methods of resolving interethnic and interpersonal contradictions. The next step in such an ever-sharpening "us" / "them" dichotomy is conceptualized within the framework of existential confrontation when for the parties the issue of resolving the contradiction inevitably leads to the question of the 
survival of "their" group and up to the physical destruction of the "them" group of opponents in this existential confrontation.

Thus, as a conclusion, we can conclude that the hypothesis of the inevitable militarization of young people's perception of patriotism in the situation of the consensus generalization around the Great Patriotic War and a meaningfully selective representation of the consolidated "us" / "them" system has been confirmed. In the course of the study, concerns were expressed about the tendency of self-reproduction of replacing the concept of "love for the Motherland" with "defense of the Motherland". A clear tendency was revealed that the apperceptional non-violence of socially significant experience, values and socially acceptable rules of behavior in relation to the Motherland is supplanted by an autopoietic projection of society-approved militarism.

\section{REFERENCES}

[1] Russian Public Opinion Research Center, Analytical review "What does it mean to be a patriot?" Retrieved from: https://wciom.ru/analyticalreviews/analiticheskii-obzor/chto-znachit-bytpatriotom

[2] Charter of the All-Russian children's and youth military-patriotic public movement "Yunarmiya" dated May 28, 2016. Retrieved from: https://yunarmy.ru/upload/iblock/ff6/Ustav_VVPO D YUNARMIYA.pdf

[3] Charter of the all-Russian public-state children's and youth organization "Russian movement of schoolchildren" as amended on November 21, 2016. Retrieved from: https://pдш.pф/uploads/22/272dbd5ee763de45f5fe 6a967e95ce.pdf?t=1537971495

[4] M.A. Rensh, T. Ryabinina, R.V. Biserov, The psychology of patriotism: the results of experimental research, international scientific and practical conference, ICNS "Science and education", 2019, pp. 224-229. Retrieved from: www.naukaip.ru

[5] A. Wilkomirska, Democratic values and patriotism the educational challenge, Phainomena Vol. 28 Iss. 110/111 (2019) 212-237.

[6] On the state "Patriotic education of citizens of the Russian Federation for 2016-2020" program: Decree of the Government of the Russian Federation as of December 30 2015, No. 1493, Collected Legislation of the Russian Federation, Iss. 2 (p. I), Art. 368, 2016. Retrieved from: http://www.szrf.ru/szrf/doc.phtml?nb=100\&issid=1 $\underline{002017043000 \& \text { docid }=106}$
[7] N. Luhmann, Institutionalisierung - Funktion und Mechanismus im sozialen System der Gesellschaft, Helmut Schelsky (Hrsg.), Zur Theorie der Institution, Gütersloh, 1970.

[8] P. Berger, T. Luckman, Social construction of reality, Treatise on the sociology of knowledge, Medium, Moscow, 1995, 323 p.

[9] Regulation of the XVI-th city interdepartmental competition of the patriotic song "I love you, Russia!", St. Petersburg, 2020. Retrieved from: http://www.balticbereg.ru/images/stories/sutur/202 0/05-2020/CGPV_27-05-2020_pesnia_poloj.doc

[10] William J., Astore, Millitarism and Education in America, Radical Teacher, 2020, pp. 21-28. 